\title{
纎維 機械の色
}

纎維機㭜も一般の機饿の色彩調節から別扱い寸るわけ にはゆかないが、出来るだけ纎維機㭜を主体にして考え てみる。総ての機饯の場合、その背景を無視して機践の 夕の色彩調節は出来ない。屋外にある機践とか建物菓輛 等子置かれた、或は莲造された、又は運転される夫々の 周囲の状況に調和した色相が探ら就、明度及び彩度も非 常にむづかしいが、考慮が拂わ礼ていなくてはならない と同様に屋内の機㖑は、幸い我々が啇当に彩色し得万室 内の色彩調節下にこれを背景として好條件比惠学机彩色 さ礼得るるのである。従つて機㭜の探色には必室内の 彩色が㭌せ考えら机る次第で㐫る。

\section{1. 在來の機械叙裝及び現在の彩色}

今迄によく見か汁る機践の彩色は注文主が色相、明度 彩度等を指定しているのは非常に少く、大体が機諓メー カ自社の特色を示すた为倸色しているのが普通であつ た。最近に至つて彩色の希望が多くなつた様子で、工場 建設等の場合特炕色彩調節の意味から一貫した指定が。 工場及び機战になされている。こ礼につれ一般既製品。 例えばモータ、扇風機、ミシン、その他にす特別の置場 の場合は別として、一番よく調和するであろろ色相を出 しているメ一カ既製品も出て来ている。何机す従来の黒 一色分ら有彩色となり、明度も彩度も大变研究されてい る。繊維機㽣の織機の例を取上げて見ると、終戦後 2 年 位迄は鋳物の肌に黒の油性ペイントで黒一色に塗りつぶ していたが、その後翰出に仵い、合成樹脂系の黒色又は 有彩色となり、こ机は主として先方の希望しそうな例え ば印度向けにはインデアンレッド、フイリッピン向けに はグリーム色色色彩調節の意味はないが塗料の品質す色 相も若千考えら礼て来ている。しかるに最近に至つて使 用者側すメーカ側も色彩調節の意義が浸透し大变考慮さ れるようになつて来た。

\section{2. 原料及び製品の色彩と機械の色彩の關係}

屋内の彩色と機战の彩色の関係は前述したが原料及び 製品と屋内との彩色北関する條件も敂論考慮されると全 様认、原料及び製品之機城も大いに関媇がある。工場内 は作業面が照明と彩色によつて立体的にものが見易くな るように、爻機械は以上と相共に作業焦点が全様な結果 を来すように彩色さ机るべきで製品の色彩が

1）無彩色飞終始一貪しているとき

2) 刻々色相、明度、彩度が変化するとさ

“方一作業每に色彩を加えるとき

以上の場合が考光られて何机の場合にす全様に良好な彩 色とゆらすのは困䧼であるが、先づ原料皮び製品を機㽣 の間の明度に差をつけること、但し余り過ぎると見合け は良くつくが眼を剌㦸して疲労を速める。次に色相を変 えて行くことも良いが何れの場合も原料製品の色彩が变
らぬ時においてのみ可能である。出来礼ば背景になる焦 点部位のみ別の互換性のある裝置をつくることも出来る と思ら。

\section{3. 機械彩色の諸條件}

\section{工場建物内部の彩色}

さて機践を設備する予定の工場内の彩色であるが、

1. 明るく立体的に

これは人工光線矛は天然光線でもよいが明るくするこ とと同時に光線の配置密度が目的物を立体的に見えるよ 万に結局目的物全面に同梯照度をあてると平面的になる し一方を多くして文対側を少くし過ぎると半面は光線が 当らず視えなくなる。この間の調制を啇当にすることで 中の機峨を文焦点に当る所を立体的に見せることが 出来る。

\section{2 ・色相、明度、彩度の調和}

色相を建物と機㭜の調和も必要であるが、纎維機栈の 場合むしろ原料及び製品と機栈の調和がより密接な場合 がある、同様に明度に特いても調和の原則を逃れること は出来ない。天节、壁、腰羽目、機㭜と夫々 $9 \cdot 8 \cdot 5$ ・6 と探るのも无である。文彩度は夫々を变えて不調和 を起させないよう1〜2位の低彩度を探ることが良いの で辺部位により変化せしめてわざわざ不調和の原因を造 る必要子ないわけである。

\section{3. 心理的な配暑}

1)物を大きく兒せたり小さく見せたり

2) 重く感ぜさせたり軽く見せたり（欢安定、不安定）

3 ) 温加人或は寒く

4) 時間の経過の長短等を取捨何礼かに重点を置く

\section{4. 生理学的な効果を取入机る}

各色相について夫々違つた反応を吾人にあたえ例えば 赤とか橙は男性生殖腺の活動を速好々か、緣色は毛細 管を拡げ血圧を隆げるとか、青は綠の反対の作用をする とか、紫は女性生殖腺の活動を促進するとかいわ机てい る。

5 . 色の物理的性質の加味

即ち照明効果照明光線の種類、反射と明度の関係も勘 案しなけ秃ばならない。

\section{6. 使用材料の選択}

折角よい計画であつても各色彩を出す材料が不適当で 変色、裉色、老化がはげしく実用価値がなくては不適当 で、容易に入手し得るすので施行せねばならない。

以上のようなことが考慮さ机て目的に添う.ように計画 されたが

\section{1) 機㭜と建物の彩色の関連}

前述の工場内部の彩色の諸條項は本項の機栈及び作業 焦点を引立てる役をするわけで、機峨は勿論この建物内 部の彩色に反することは出来ない。しかし時と場合によ 
り色相の調和は余り考える必要のない時もある。即ち余 り離れている時、或は機栈が原料製品でかくされている 場合、問題になら程の大きさの場合等々で、綜合的比 は原料及び製品、建物の彩色等が機践の彩色の諸條件隹 なり、併せて伦险、注意、焦点色を附加すると一簤完備 する。

\section{4. 色彩色の選び方}

繊維工場では女子彷業者の数が多い場所が多々あり。 こ机等の人の意志を尊重するつわりで色見本カードを見 せてどの色が好きかとゆう人気投票で、女子は例えば赤 が好きだとゆうことで工場も機㭜も真赤に塗つたとする とこれは大きな間違いであろろ。人気投票で女子の好き な色相を選ぶこと迄は良いが、その利用法が誤つている といえる。好き嫌いと工場等に括计る能率とゆうことと は必ずしも一致しないもので小さなカードと大きな部屋 の内部全体、或は機峨の関係一時的体刺战さ机て快感を 感ずるが長時間ではどんな疲労状況を呈するとか、娛楽 の場合と仕事をする場合、運動商技の場合とかを考えに 入れるべき多くの問題が岗ることを忘れてはならない。

"緑の牧場で働く事は砂漠の中で働くより良い"に決 つているが、度を越して百花㵵漫と知き乱礼一面の花毛 矰を數き詰めたように迄になると仕事をするより遊ぶ方 が適当ということになろら。

そこで一面人の呰好す考えに大れるにしても、これる あく迄種々の資料から材料を得て理論的にやるべきであ つて、しが尔色相明度彩度と各々選択すべきである。

\section{5. 色彩の具体 例}

工場探色の一般無難な例を採つて機峨の色彩を考えて みると $\mathrm{A} \cdot 2.5 \mathrm{Y}, \mathrm{B} \cdot 2.5 \mathrm{G}, \mathrm{C} \cdot 3 \mathrm{~B}, \mathrm{D} \cdot 2.5 \mathrm{P} \mathrm{B}$ (繊
以上のよろに工場内部々の調和は各々若干異り全部が 共通ではないが、余り調和を重要視する必要のない時は 2 GY から G.B G を経て 4 B 迄広い範囲になり、この 内から適当に択び明度に拘いてはこ礼子種々考えて 7〜 5 の間に殆しど納まり、又彩度も1〜2 とゆう極めて低 いるのが原則とされている。

その外可動部位、何険部分、焦点部分を明示色、注意 色、焦点色等を用いて標示すべきであるが、一般に織維 機諓は可動部分が非常に多いので余り異つた色柇を施す と使用者か胘惑さ礼て、却つて疲労を增し能率の低下を 起すことほなる。㵶維機械、織機を例にとると哥る機线 は 575 種の部品から組立てられ。しかも大半が可動部分 で、こ机等は殆んぞ機峨本体と同一彩色注すべきでハン ドルその他を焦点色に、プーリ、シャフトの一部を注意 色に、給油孔を白色文は赤色で、その他はこれ等に準じ て彩色乙余り多様な色彩は面白くない。

\section{6. 纖維機械の探色材料に具備すべき要件}

\section{1) 変色裉色の少ないこと}

变色褪色が絕体にないような塗料はなかなか製造困難

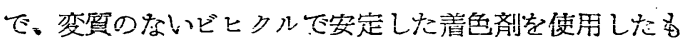
のが適当である。

2）耐油性であること

機諓には注油孔があり、給油の時漏出したり污れをガ ソリン等を以つて洗了時、污机はとれても塗料が剝れな いようなるのでなくてはならない。

3 ) 密着性の良好なこと

密着性の良いことは何れの場合でも必要であるが、塗 裝することが度々出来蜼い機㭜類は特に考えねばならな い。

4) 耐䁻耗性の良いこと

機械的に表面から消耗の程度の少いるので、据扵けた

\begin{tabular}{|c|c|c|c|c|c|c|c|}
\hline \multicolumn{2}{|c|}{ 建物 の色相 } & 調 & 和 & 補 & 調 & 和 & 色 \\
\hline A & $2.5 \mathrm{Y}$ & (1) & $2 \mathrm{G} \mathrm{Y} \leftrightarrow 7 \mathrm{G} \mathrm{Y}$ & $2 \mathrm{~B} \mathrm{G} \leftrightarrow 55 \mathrm{P} \mathrm{B}$ & . & & \\
\hline B (ホ) & $2.5 \mathrm{G}$ & (ㅁ) & $2 \mathrm{~B} \mathrm{G} \leftrightarrow 7 \mathrm{~B} \mathrm{G}$ & $2 \mathrm{P} \mathrm{B} \leftrightarrow 5 \mathrm{P} \mathrm{B}$ & & $9 \mathrm{Y}$ & $\leftrightarrow 4 \mathrm{G} \mathrm{Y}$ \\
\hline$C(n)$ & $3 \mathrm{~B}$ & & $2 \mathrm{P} \mathrm{B} \leftrightarrow 7 \mathrm{P} \mathrm{B}$ & $2.5 \mathrm{Y} \leftrightarrow 44 \mathrm{G} \mathrm{Y}$ & $(x)$ & $9 \mathrm{G}$ & $\leftrightarrow 4 \mathrm{~B} \mathrm{G}$ \\
\hline $\mathbf{D}$ & 2.5 P B & & & $2.5 \mathrm{Y} \leftrightarrow 4 \mathrm{G}$ & $\Leftrightarrow$ & $9 \mathrm{~B} \mathrm{G}$ & $\leftrightarrow 4 \mathrm{~B}$ \\
\hline
\end{tabular}

機狨等には自然做燥 性の材料でないと塗 装が面倒である。機 㭜メーカでは部品等 は小規模の炬があれ ばよいので、焼付塗

維関係以外工場には余り好まれない）以上の色相の附近 かと考えら礼る。

建物の色相は単一色相の場合、或は機峨と一番関連性 が梁い場所の色相が建物の色相と考兵ると、建物と同一 色相のものは全部調和するし、その他10種の調和色及び 補色が夫々調和している。しかし機械色として凡ゆる方 面から検討するとAの時は（イ）、Bの時は（口）と （木）、Cの時は（ハ）と(へ)、Dの時は (二) 位比 特別の考えのない限り機峨色として選ばれると思 万。
裝をやると酎磨耗性の勝れた硬度の高い染膜が得られ る。

\section{5 ）醇薬品性}

多くの場合酸、アルカリ、硫黄化合物に耐える必要が あり、使用場所によつては化学薬品の飛沫を直接受ける 場合もあり、普通の場合でも湿度が非常に高く耐水性で あることは勿論である。

備考、以上の内色彩炕関する数字はマン女ル記号でを， る。 